\title{
Co-application of biochar and cattle manure counteract positive priming of carbon mineralization in a sandy soil
}

\author{
Daniel E. Dodor ${ }^{* *}$, , Yahaya J. Amanor ${ }^{1}$, Festus T. Attor ${ }^{1}$, Thomas A. Adjadeh', Dora Neina ${ }^{1}$ \\ and Michael Miyittah²
}

\begin{abstract}
Background: Application of biochar has been suggested as a carbon (C) management strategy to sequester $C$ and enhance soil quality. An incubation study was carried out to investigate the interactive effect of biochar and cattle manure application on mineralization of carbon (C) in a tropical coastal savanna sandy soil.

Methods: The soils were amended with three sole levels of cattle manure $\left(0,13\right.$ and 26 tons ha $\left.{ }^{-1}\right)$ or biochar $(0,20$ and 40 tons ha ${ }^{-1}$ ) and four combined manure-biochar levels (20 or 40 tons ha ${ }^{-1}$ biochar plus 13 or 26 tons ha $^{-1}$ manure) and $\mathrm{CO}_{2}$ evolution was measured over 56 days incubation period. The soils were analyzed for mineral $\mathrm{N}$ $\left(\mathrm{NH}_{4}{ }^{+}-\mathrm{N}\right.$ and $\left.\mathrm{NO}_{3}{ }^{-}-\mathrm{N}\right)$ and water extractable organic $\mathrm{C}$, and net $\mathrm{N}$ mineralization, and priming effect (PE) values calculated.

Results: The cumulative $\mathrm{C}$ mineralized increased in the sole manure and biochar amended soils, resulting in 45-125\% positive PE. However, co-application of biochar and manure decelerated decomposition of C, probably through adsorption of labile $\mathrm{C}$ and net $\mathrm{N}$ immobilization, subsequently leading up to negative $35 \% \mathrm{PE}$.

Conclusions: The results suggest that co-application of biochar and cattle manure can potentially stabilize $\mathrm{C}$ in manure amended sandy soils, albeit with a temporary mineral $\mathrm{N}$ limitation to plants.
\end{abstract}

Keywords: Biochar, Cattle manure compost, C sequestration, Priming effect, Sandy soil, Soils organic matter

\section{Background}

Addition of organic substrate of virtually any form to soil can stimulate microbial growth and activity, resulting in mineralization of soils organic carbon (SOC) to different extents. The short-term increase or decrease in mineralization of native SOC following addition of a fresh organic substrate is referred to as positive or negative priming effect, respectively (Kuzyakov et al. 2000). For example, addition of catechol has been shown to reduce mineralization of SOC (negative priming effect) in a Haplic Podzol, while oxalic acid induced negative as well as positive priming effects in the same soil (Hamer and Marschner 2005a).

\footnotetext{
*Correspondence: dedodor@ug.edu.gh

1 Department of Soil Science, University of Ghana, Legon-Accra, Ghana Full list of author information is available at the end of the article
}

Recently, application of biochar, a solid material rich in $\mathrm{C}$ that is produced from pyrolysis of organic materials under limited oxygen condition, has been suggested as an alternative carbon (C) management strategy to promote C sequestration (Sohi et al. 2010). Biochar is regarded as a chemically and biologically stable $C$ pool that can influence soil physico-chemical properties and increase SOC content (Sohi et al. 2010). Application of biochar has been reported to result in decreased mineralization of native SOC (Zimmerman et al. 2011). Working with some Brazilian soils, Liang et al. (2010) reported that sugarcane residues were incorporated into soil aggregates more rapidly in biochar-rich compared to biochar-poor soils, resulting in a net decrease in $\mathrm{C}$ mineralization. The observed negative priming of SOC have been attributed to the divergence of microorganisms or their enzymes from biochar to other more easily oxidizable organic 
residues, or the introduction of inhibitors associated with the addition of a new substrate (Cross and Sohi 2011; Jones et al. 2011; Zavalloni et al. 2011; Whitman et al. 2013).

Biochar, however, may contain enough labile C (Zimmerman 2010; Luo et al. 2011) and high nutrient levels that can prime soil microbes to induce the production of extracellular enzymes to degrade native SOC through co-metabolism (Kuzyakov et al. 2000; Zimmerman et al. 2011). A significant loss of native SOC following biochar addition to a forest soil (positive priming effect) was reported by Wardle et al. (2008). The indirect changes in soil microbial activity triggered by the addition of biochar, resulting in increased mineralization of native SOC can influence microbial $\mathrm{C}$ cycling processes in soils. Other researchers, however, have reported no effect on SOC mineralization following biochar application (Kuzyakov et al. 2009; Novak et al. 2010). The combined application of biochar and organic amendments such as green and pig manures have also been shown to result in increased $\mathrm{CO}_{2}$ efflux compared to individual applications (Luo et al. 2011; Troy et al. 2013). Other workers have also reported negative priming effect on SOC following the combined application of biochar and organic amendments (Rogovska et al. 2011).

Application of biochar can serve as an alternative C management strategy to improve soils quality for sustainable agricultural production in sandy soils low in fertility. Few studies have evaluated the influence of biochar application with or without organic amendments on mineralization of SOC in sandy soils of the temperate and tropical regions (Novak et al. 2010; Lu et al. 2014; Rittl et al. 2015). However, to the best of our knowledge, no study has evaluated biochar $\mathrm{C}$ mineralization in the important sandy agricultural soils of the dry equatorial coastal savanna regions. Therefore, the objectives of the present study were to (i) evaluate the interactive effects of sole and combined application of rice husk biochar and cattle manure on $\mathrm{C}$ mineralization, and (ii) quantify water extractable organic $\mathrm{C}$ and mineral $\mathrm{N}$ to ascertain the influence of $\mathrm{C}$ and $\mathrm{N}$ interactions on $\mathrm{C}$ mineralization in a sandy agricultural soil from the dry equatorial coastal savanna region of Ghana.

\section{Methods}

\section{Soil and study area}

The soil used in the present study belongs to the Keta series, a well sorted homogenous sandy soil found in the semi-arid costal savanna zone of Ghana. The soils are located on scattered sandbars and a large sand spit made up of marine sands that form narrow elongated beach ridges with narrow depressions. The soils are naturally low in fertility due to their sandy nature. It is classified as a Psamment based on the USDA system of classification. The climate of the area is dry equatorial with mean temperature of $28{ }^{\circ} \mathrm{C}$ and unevenly distributed mean annual rainfall below $900 \mathrm{~mm}$. The soils are cultivated intensively following the application of cattle and poultry manures every growing season.

Surface soil $(0-20 \mathrm{~cm}$ depth) samples were collected from uncultivated fields in Anloga, located in the Keta District of the Volta Region in southeast Ghana (Longitude: $0^{\circ} 53^{\prime} 50.21^{\prime \prime} \mathrm{E}$, Latitude: $\left.5^{\circ} 47^{\prime} 41.03^{\prime \prime} \mathrm{N}\right)$. The soil samples were air dried and passed through a 2-mm sieve. Soil $\mathrm{pH}$ was measured in 1:1 soil to water suspension, and particle size distribution was determined using the hydrometer method (Gee and Bauder 1986). Total C and $\mathrm{N}$ were determined on $<180 \mu \mathrm{m}$ air-dried samples by dry combustion (LECO CNS Analyzer, LECO Corp., St. Joseph, MI). Some selected initial chemical and physical properties of the soil used are summarized in Table 1.

\section{Cattle manure and biochar}

Matured cattle manure was collected from a farmer's field, air-dried and crushed to pass through $2 \mathrm{~mm}$ sieve. The biochar used was produced from rice husk. After drying, the feedstock was cut into small pieces and pyrolyzed at a temperature of $500{ }^{\circ} \mathrm{C}$ using a kiln. The resulting biochar was allowed to cool to room temperature, crushed and passed through $2 \mathrm{~mm}$ sieve to give a uniform size fraction, but were not exposed to any aging treatment (e.g., composting, steam or oxidation treatment) before application to the soils. Total $\mathrm{C}$ and $\mathrm{N}$ contents of the manure and biochar were measured using LECO CNS Analyser (LECO Corp., St. Joseph, Michigan). Selected properties of the manure and biochar used in the study are summarized in Table 1.

\section{Experimental procedure}

The experimental design consisted of three levels of manure $\left(0,13\right.$, and 26 tons $\left.\mathrm{ha}^{-1}\right)$ and biochar $(0,20$, and

Table 1 Selected chemical and physical properties of the soil, cattle manure and biochar used

\begin{tabular}{|c|c|c|c|}
\hline Properties & Soil & Biochar & Cattle manure \\
\hline $\mathrm{pH}$ (water) & 7.6 & 10.5 & 7.9 \\
\hline Total C $\left(\mathrm{g} \mathrm{kg}^{-1}\right)$ & 2.6 & 490 & 262 \\
\hline Total $\mathrm{N}\left(\mathrm{g} \mathrm{kg}^{-1}\right)$ & 0.18 & 1.6 & 11.3 \\
\hline $\mathrm{C} / \mathrm{N}$ ratio & 14 & 306 & 23 \\
\hline Mineral $\mathrm{N}\left(\mathrm{mg} \mathrm{kg}^{-1}\right)$ & 30.30 & 25.9 & 211 \\
\hline CEC $\left(\mathrm{cmol} \mathrm{kg}^{-1}\right)$ & 1.93 & 26.1 & 62.5 \\
\hline Sand (\%) & 87.5 & - & - \\
\hline Silt (\%) & 10.0 & - & - \\
\hline Clay (\%) & 2.4 & - & - \\
\hline Textural class & Sand & - & - \\
\hline
\end{tabular}


40 tons $\mathrm{ha}^{-1}$ ) which were factorially combined to give a total of nine treatments. Detail description of the treatment combinations used, $\mathrm{C}$ added, and their codes are shown Table 2.

The manure and/or biochar were mixed thoroughly with the soils, placed in $1.5 \mathrm{~L}$ French square jars, moistened to $60 \%$ water holding capacity (WHC) and incubated at $25 \pm 1{ }^{\circ} \mathrm{C}$ for 56 days. No $\mathrm{N}$ fertilizer was added, and each treatment was replicated three times. Beakers containing $10 \mathrm{~mL}$ of $1 \mathrm{M} \mathrm{NaOH}$ were placed in each jar to capture $\mathrm{CO}_{2}$ efflux during the incubation. The $\mathrm{NaOH}$ solution was changed daily during the first week and weekly thereafter. The $\mathrm{CO}_{2}$ trapped in the $\mathrm{NaOH}$ was back-titrated with $0.1 \mathrm{M} \mathrm{HCl}$ using phenolphthalein as an indicator after precipitation of the carbonate with $2 \mathrm{M} \mathrm{BaCl}_{2}$. All treatments were corrected for $\mathrm{CO}_{2}$ using a blank setup. The moisture content of the jars was maintained at $60 \%$ WHC throughout the incubation period by weighing and addition of distilled water if needed.

After incubation, the soils were analyzed for total amount of mineral $\mathrm{N}$ (sum of $\mathrm{NH}_{4}-\mathrm{N}$ and $\mathrm{NO}_{3}-\mathrm{N}$ ) by extracting $5 \mathrm{~g}$ of the moist soils with $50 \mathrm{~mL}$ of $2 \mathrm{M} \mathrm{KCl}$. The amount of $\mathrm{NH}_{4}$ and $\mathrm{NO}_{3}-\mathrm{N}$ were determined by the steam distillation method described by Mulvaney (1996). The net $\mathrm{N}$ mineralization (NNM) was calculated from the difference between extractable mineral $\mathrm{N}$ from each treatment and the control without amendment. Positive value indicates NNM and negative value was considered $\mathrm{N}$ immobilization. Water extractable OC (WEOC) content of the treated soils were extracted with distilled water and the $\mathrm{C}$ concentration determined by the wet oxidation method (Walkley and Black 1934).

\section{Calculation of net $\mathrm{CO}_{2}-\mathrm{C}$ efflux and priming effect}

The net cumulative $\mathrm{CO}_{2}-\mathrm{C}$ efflux from biochar and/or manure treated soils were calculated using the following equation:
$\mathrm{CO}_{2}-C_{(\mathrm{Net})}=\mathrm{CO}_{2}-C_{(\text {treatment })}-\mathrm{CO}_{2}-C_{(\text {control })}$

where, $\mathrm{CO}_{2}-\mathrm{C}$ (treatment) is the cumulative $\mathrm{CO}_{2}-\mathrm{C}$ efflux from soils amended with biochar and/or manure, and $\mathrm{CO}_{2}-\mathrm{C}$ (control) is the $\mathrm{CO}_{2}-\mathrm{C}$ evolved from soils without amendment.

To evaluate the effect of the combined application of manure and biochar on $\mathrm{C}$ mineralization, the net $\mathrm{CO}_{2}-\mathrm{C}$ evolved from the sole manure and biochar amended soils were compared with that from the corresponding combined manure-biochar treatment. Priming effect was calculated using the following equation:

Priming effect(\%)

$$
=\frac{\left[\mathrm{CO}_{2}-C_{(\text {treatment })}-\mathrm{CO}_{2}-C_{(\text {control })}\right]}{\mathrm{CO}_{2}-C_{(\text {control })}} \times 100
$$

where $\mathrm{CO}_{2}-\mathrm{C}_{\text {(treatment) }}$ and $\mathrm{CO}_{2}-\mathrm{C}_{\text {(control) }}$ have the same meaning as in Eq. (1) above. This simple method for estimating priming effect of organic substrate addition on $\mathrm{C}$ mineralization has been used by several authors (Hamer et al. 2004; Hamer and Marschner 2005a, b; Novak et al. 2010; Zimmerman et al. 2011; Watanabe and Sato 2015; Riaz et al. 2017).

\section{Statistical analysis}

Duncan's multiple range test was used to compare treatments means, and a $\mathrm{P}<0.05$ was considered statistically significant. All statistical analyses were done using SigmaPlot 11.0, and figures were drawn using GraphPad Prims 7 for windows.

\section{Results}

Total and net $\mathrm{CO}_{2}$ evolution

The general pattern of $\mathrm{CO}_{2}-\mathrm{C}$ evolution from the various treatments were a sharp increase in the first week followed by a steady decrease thereafter till the end of the

Table 2 Experimental treatments for evaluating the effect of biochar and manure on C mineralization in a sandy soil

\begin{tabular}{|c|c|c|c|c|c|}
\hline \multirow[t]{2}{*}{ Treatment code } & \multicolumn{2}{|l|}{ Manure } & \multicolumn{2}{|l|}{ Biochar } & \multirow[t]{2}{*}{ Total initial $\mathrm{C}(\mathrm{g} C)$} \\
\hline & Rate (tons ha ${ }^{-1}$ ) & Code & Rate (tons ha ${ }^{-1}$ ) & Code & \\
\hline MOBO (control) & 0 & MO & 0 & $\mathrm{BO}$ & 2.60 \\
\hline MOB20 & 0 & MO & 20 & B20 & 6.01 \\
\hline MOB40 & 0 & MO & 40 & B40 & 8.43 \\
\hline M13B0 & 13 & M13 & 0 & $\mathrm{BO}$ & 3.59 \\
\hline M13B20 & 13 & M13 & 20 & B20 & 7.00 \\
\hline M13B40 & 13 & M13 & 40 & B40 & 9.42 \\
\hline M26B0 & 26 & M26 & 0 & $\mathrm{BO}$ & 4.58 \\
\hline M26B20 & 26 & M26 & 20 & B20 & 7.99 \\
\hline M26B40 & 26 & M26 & 40 & B40 & 10.41 \\
\hline
\end{tabular}


56 days incubation period (data not shown). The effect of sole application of biochar and manure on total $\mathrm{CO}_{2}-\mathrm{C}$ efflux are shown in Fig. 1a. Regardless of treatment type, the amount of $\mathrm{CO}_{2}-\mathrm{C}$ evolved from the non-amended control soils were always lower than that from the soils amended with either manure or biochar. Sole application of manure (M13B0 and M26B0) significantly $(\mathrm{p}<0.05)$ increased the total $\mathrm{CO}_{2}$ - $\mathrm{C}$ efflux up to 1.9 and 2.2 times compared to the control (Fig. 1a). The total $\mathrm{CO}_{2}$-C efflux increased with increasing rate of manure application, with total $\mathrm{CO}_{2}$-C efflux from the M26B0 been 1.2-fold higher and significantly $(\mathrm{p}<0.05)$ different from that evolved from the M13B0 treatment (Fig. 1a).

Sole application of biochar resulted in significantly $(\mathrm{p}<0.05)$ higher total $\mathrm{CO}_{2}-\mathrm{C}$ efflux compared to the control throughout the 56 days of incubation. As with the sole manure applications, there was significantly $(\mathrm{p}<0.05)$ higher total $\mathrm{CO}_{2}$-C efflux from the higher (M0B40) compared to the lower biochar application rate (MOB20). Comparing the sole application of manure and biochar, the M26B0 treatment evolved significantly $(\mathrm{p}<0.05)$ higher $\mathrm{CO}_{2}-\mathrm{C}$ than the two biochar treatments (M0B20 and M0B40) (Fig. 1a). The total $\mathrm{CO}_{2}-\mathrm{C}$ efflux from the M13B0 treatment was significant $(\mathrm{p}<0.05)$ higher than that from the lower biochar application rate (M0B20) (Fig. 1a).

The total $\mathrm{CO}_{2}-\mathrm{C}$ efflux from soils that received combined application of biochar and manure showed increased $\mathrm{CO}_{2}-\mathrm{C}$ efflux compared to the sole treatments (Fig. 1b). The total $\mathrm{CO}_{2}$-C efflux from the M26B40 treatment was significantly $(p<0.05)$ higher than that from all the combined biochar-manure treatments, except from the M26B20 where the difference was not significant ( $p>0.05$; Fig. $1 b$ ). The total $\mathrm{CO}_{2}-\mathrm{C}$ evolved from the M13B40 was not significantly $(p>0.05)$ different from that from the M13B20 treatment.

Sole application of manure resulted in significantly $(\mathrm{p}<0.05)$ higher net $\mathrm{CO}_{2}-\mathrm{C}$ efflux than that from sole application of biochar. The net $\mathrm{CO}_{2}-\mathrm{C}$ evolved from both sole biochar and manure treatments increased with increasing application rates. The net $\mathrm{CO}_{2}-\mathrm{C}$ effluxes from the combined application of biochar and manure were significantly $(\mathrm{p}<0.05)$ lower than that of the sum of the net $\mathrm{CO}_{2}-\mathrm{C}$ evolved from the sole applications. The ANOVA showed that $\mathrm{C}$ mineralization as measured by cumulative and net $\mathrm{CO}_{2}$-C efflux were affected by manure and biochar application rates, as well as manure $\times$ biochar interactions (Table 3 ).
A
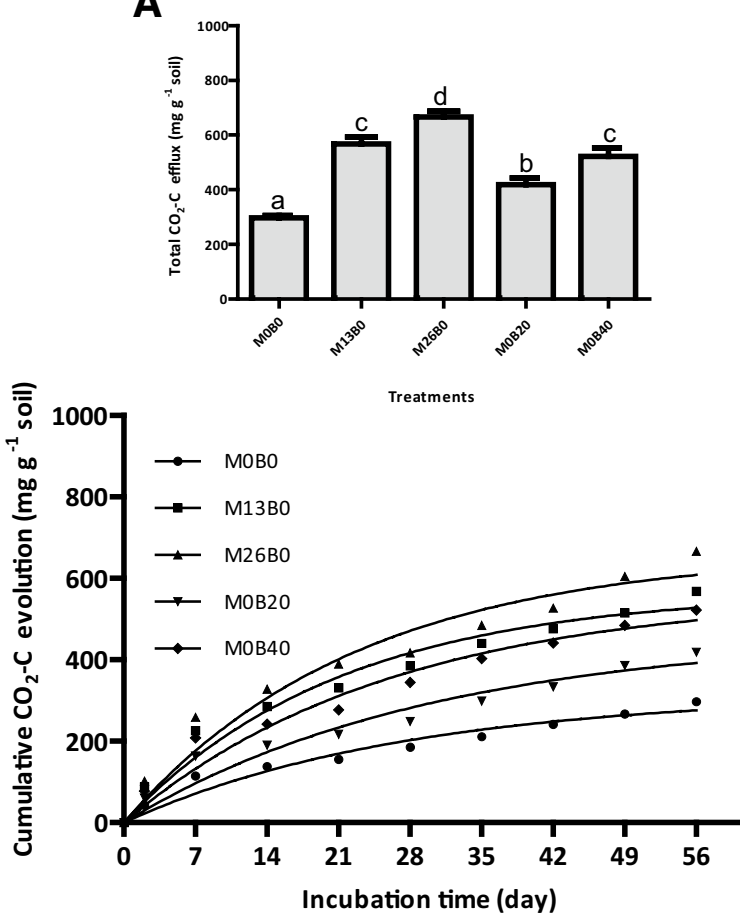

B
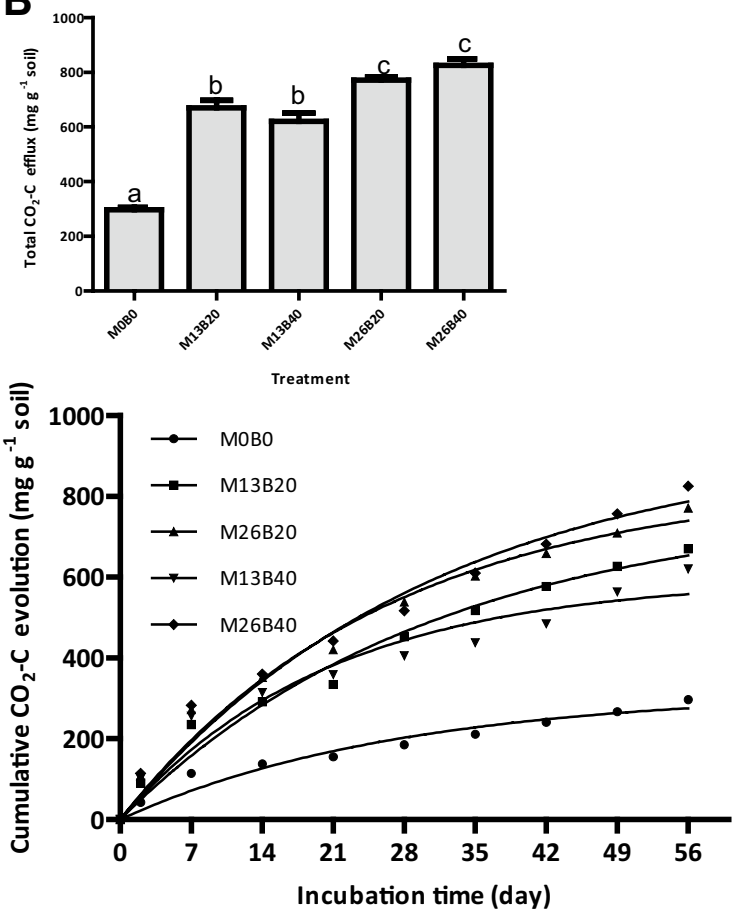

Fig. 1 Cumulative and total $\mathrm{CO}_{2}$ efflux from incubation of soils amended with $\mathbf{A}$ sole manure (M) or biochar (B), and $\mathbf{B} \mathrm{M}$ combined with $\mathrm{B}$ over 56 days. Insets show total $\mathrm{CO}_{2}$ efflux. Same letter (s) above the bars indicate no significant difference between treatments at $\mathrm{p}=0.05$. Vertical bars represent standard error of the means $(n=3)$. M0, M13 and M26 are M rate at 0,13 and 26 tons ha ${ }^{-1}$, respectively. B0, B20 and B40 are B rate at 0,20 and 40 tons ha ${ }^{-1}$, respectively 
Table 3 Summary of analysis of variance of treatment effect on cumulative and net $\mathrm{CO}_{2}-\mathrm{C}$ efflux

\begin{tabular}{llrc}
\hline Parameter & Source of variance & F value & Significance \\
\hline Cumulative $\mathrm{CO}_{2}$-C efflux & Manure & 156.96 & $<0.001$ \\
& Biochar & 30.47 & $<0.001$ \\
& Manure $\times$ biochar & 4.09 & 0.016 \\
\multirow{2}{*}{$\mathrm{Net} \mathrm{CO}_{2}$-C efflux } & Manure & 114.55 & $<0.001$ \\
& Biochar & 16.26 & $<0.001$ \\
& Manure $\times$ biochar & 3.86 & 0.031 \\
\hline
\end{tabular}

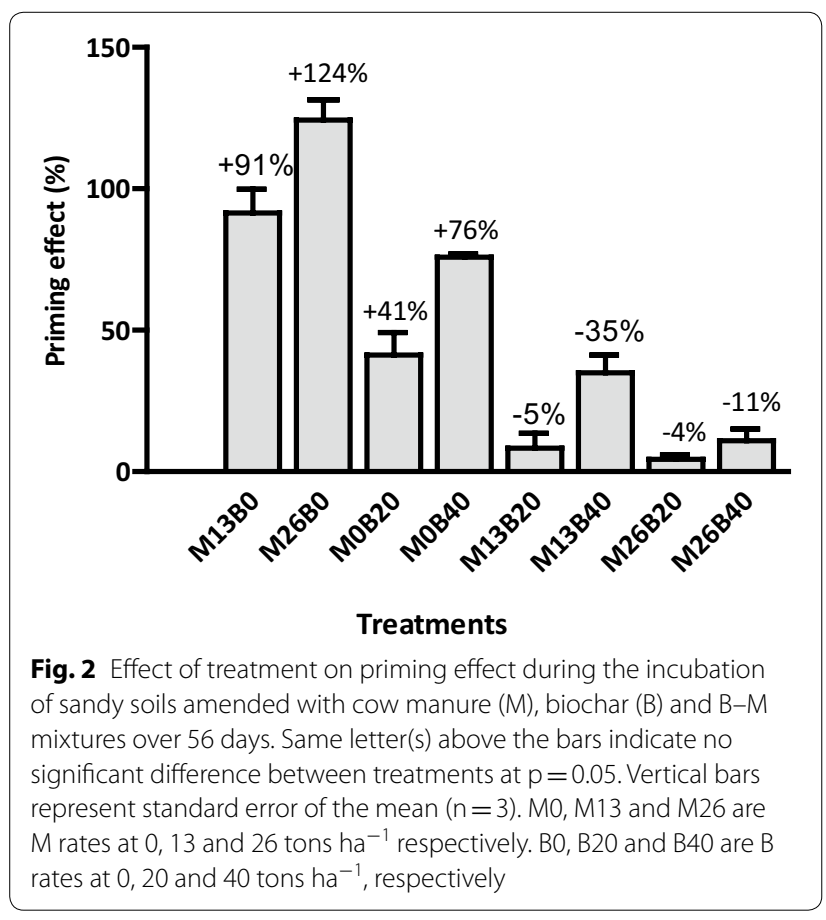

\section{Priming effect}

Sole application of manure resulted in positive priming effect of 91 and $124 \%$ at the 13 and 26 tons ha ${ }^{-1}$ application rates, respectively; equivalent to additional 272 and

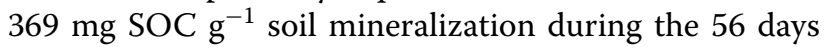
incubation (Fig. 2). Although sole applications of biochar also resulted in priming of $\mathrm{SOC}$, the calculated positive priming effect of 41 and $76 \%$, corresponding to additional 122 and $225 \mathrm{mg} \mathrm{SOC} \mathrm{g}^{-1}$ soil mineralization, respectively for 20 and 40 tons ha ${ }^{-1}$ biochar rates were significantly $(\mathrm{p}<0.05)$ lower than those for the manure treatments. Combined application of manure and biochar resulted in decreased mineralization of SOC (negative priming effect, Fig. 2) relative to the sum of the sole applications of manure and biochar. The calculated negative priming effect ranged from -4.0 to $-35 \%$, corresponding to
17-173 mg less $C$ mineralization after 56 days of incubation. For a given manure rate, increasing biochar application rate resulted in higher negative priming effect (Fig. 2). The highest negative priming effect of $35 \%$ was calculated for the M13B40 treatment (Fig. 2).

\section{Water extractable organic carbon (WEOC) and net $\mathrm{N}$ mineralization (NNM)}

The effect of the various treatments on WEOC is presented in Fig. 3. Both sole biochar and manure-biochar applications resulted in significant increase in WEOC content compared to the control. The WEOC content of soils treated with biochar were significantly higher than that in the manure treated soils. The WEOC was positively and significantly correlated with cumulative $\mathrm{CO}_{2}$ efflux (Fig. $4 ; \mathrm{r}=0.862 ; \mathrm{p}=0.003$ ).

The mineral $\mathrm{N}\left(\mathrm{NH}_{4}{ }^{+}\right.$and $\left.\mathrm{NO}_{3}{ }^{-}-\mathrm{N}\right)$ content of the soils after 56 days of incubation were significantly higher in the sole application of manure and biochar soils compared to the control and co-applied manure and biochar (Fig. 5). The mineral $\mathrm{N}$ content of biochar amended soils were significantly $(\mathrm{p}<0.05)$ higher than those of manure amended soils. All sole applications of manure and biochar resulted in positive NNM, whereas combined applications resulted in negative $\mathrm{N}$ mineralization or $\mathrm{N}$ immobilization (Table 4). The highest negative NNM or immobilization of $-33.13 \mu \mathrm{g} \mathrm{N} \mathrm{kg}{ }^{-1}$ soil was recorded in the M26B20 treatment. The NNM was negatively and significantly correlated with net $\mathrm{CO}_{2}$-C evolution.

\section{Discussion}

\section{Total and net $\mathrm{CO}_{2}-\mathrm{C}$ evolution}

The higher total $\mathrm{CO}_{2}-\mathrm{C}$ efflux from the sole manure amended soils (M13B0 and M26B0) compared to the control (M0B0), as well as the increased $\mathrm{CO}_{2}$-C efflux with increasing application rates are attributable to the significantly higher content of easily oxidizable C pool, which is consistent with many previous studies that reported rapid increase in $\mathrm{C}$ mineralization following addition of labile $C$ substrates to soils (Hamer et al. 2004; Hamer and Marschner 2005b; Troy et al. 2013; Riaz et al. 2017). Mineralization of organic amendments including poultry manure, straw compost and vermicompost were reported to vary depending on the quality of $\mathrm{C}$ content (Flavel and Murphy 2009). The increased $\mathrm{CO}_{2}-\mathrm{C}$ evolution following biochar addition compared to the control confirmed previous reports that biochar contains bioavailable $C$ fractions in the form of aliphatic and volatile OCs that were respired by microorganisms (Qayyum et al. 2012; Ameloot et al. 2013; Sigua et al. 2014). Biochar produced at $250-650{ }^{\circ} \mathrm{C}$, which is comparable to the one used in the present study was reported to provide labile $\mathrm{C}$ from bio-oil condensates formed during 


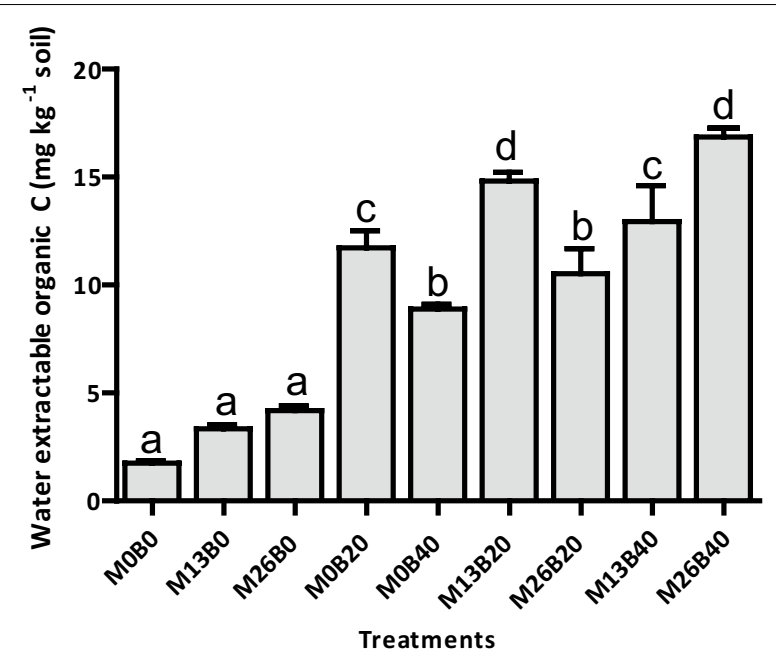

Fig. 3 Effect of treatment on WEOC during the incubation of sandy soils amended with cow manure (M), biochar (B) and B-M mixtures over 56 days. Same letter(s) above the bars indicate no significant difference between treatments at $p=0.05$. Vertical bars represent standard error of the mean $(n=3) . M 0, M 13$ and M26 are M rates at 0 , 13 and 26 tons ha ${ }^{-1}$ respectively. BO, B20 and B40 are B rates at 0,20 and 40 tons ha ${ }^{-1}$, respectively

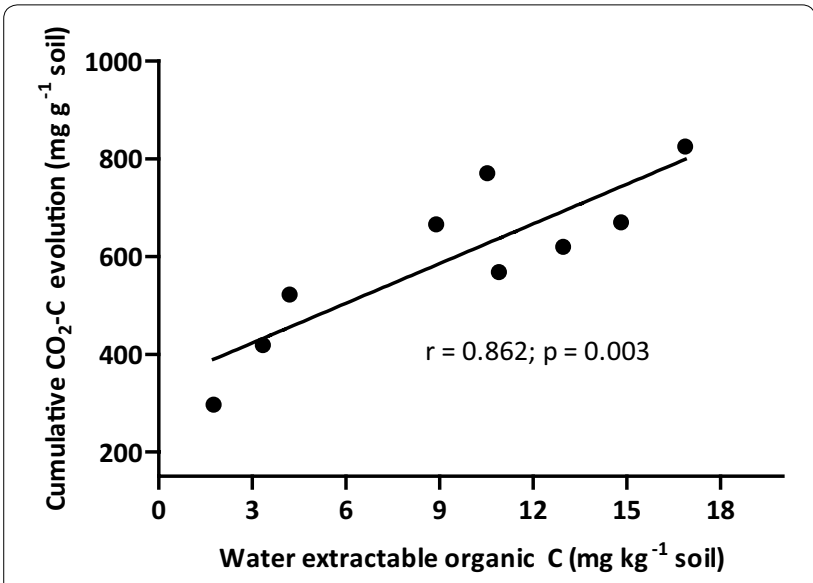

Fig. 4 Relationship between cumulative $\mathrm{CO}_{2}$ efflux and water extractable organic carbon

pyrolysis to soil microorganisms (Smith et al. 2010; Zimmerman et al. 2011). On the other hand, other researchers have reported that biochar application did not result in significant $(\mathrm{p}>0.05) \mathrm{CO}_{2}$-C evolution compared to the control soils (Grunwald et al. 2016; Riaz et al. 2017). The increased in the total $\mathrm{CO}_{2}-\mathrm{C}$ evolution with increasing rate of biochar amendment is consistent with the results of Smith et al. (2010) who reported increased $\mathrm{CO}_{2}$-C evolution in soils amended with switchgrass biochar pyrolyzed at $500{ }^{\circ} \mathrm{C}$, which increased with increasing rates of biochar application due to increased labile $\mathrm{C}$ added at higher rates.

The higher net $\mathrm{CO}_{2}-\mathrm{C}$ evolved from the biochar amended compared to unamended control soils agrees with Sigua et al. (2014) who reported higher net $\mathrm{CO}_{2}-\mathrm{C}$ evolution in soils amended with manure and lignocellulosic-based biochar compared to the unamended soils, with $\mathrm{C}$ mineralization rates decreasing with increasing particle sizes of the biochars used. The significant higher cumulative and net $\mathrm{CO}_{2}-\mathrm{C}$ efflux from the manure compared to that from the biochar amended soils were probably due to the former containing more easily mineralizable $\mathrm{C}$ compounds that were preferentially mineralized by microbes (Zavalloni et al. 2011). The results are in consonance with those of other workers who reported higher net $\mathrm{CO}_{2}-\mathrm{C}$ efflux in soils amended with crop residues, including corncob and legume, compared to biochar amended soils (Watanabe and Sato 2015; Riaz et al. 2017), but disagree with those of Novak et al. (2010) showing that switchgrass added to soils was not mineralized readily. Slower net $\mathrm{CO}_{2}-\mathrm{C}$ evolution rates in biochar compared to plant residues amendment have also been reported by Hamer et al. (2004), with the rate decreasing further after 3 months of its addition to the soils (Kuzyakov et al. 2009). The lower net $\mathrm{CO}_{2}-\mathrm{C}$ efflux in soils that received combined application of manure and biochar compared to the sum of the net $\mathrm{CO}_{2}-\mathrm{C}$ in sole applications agree with the results of Zavalloni et al. (2011) but contradict those of Watanabe and Sato (2015) showing greater net $\mathrm{CO}_{2}-\mathrm{C}$ evolution when biochar and organic amendment were applied simultaneously compared to the sum of the net $\mathrm{CO}_{2}$ - $\mathrm{C}$ evolved from sole amendment with biochar and organic amendment.

\section{Priming effect}

The observed positive priming effects following sole application of manure and biochar are consistent with previous studies that reported increased mineralization of SOC following addition of labile organic $\mathrm{C}$ substrates to soils (Hamer et al. 2004; Hamer and Marschner 2005a, b). The calculated positive priming effect of SOC ranging between 41 and $76 \%$ in the 20 and 40 tons ha ${ }^{-1}$ biochar amended soils, respectively are within the range reported by Luo et al. (2011) for soils of varied pH values. Bamminger et al. (2013) reported 85 and $141 \%$ positive priming effect in arable soils amended with 20 and $40 \%$ maize derived-hydrochar, respectively. Using labeled biochar, Zimmerman et al. (2011) showed that biochar addition to soils can show both stimulative and inhibitive effects on mineralization of SOC. It should be pointed out that attribution of apparent or real priming effect requires the use of isotopically labeled organic substrates, which was not employed in the present study. However, given 


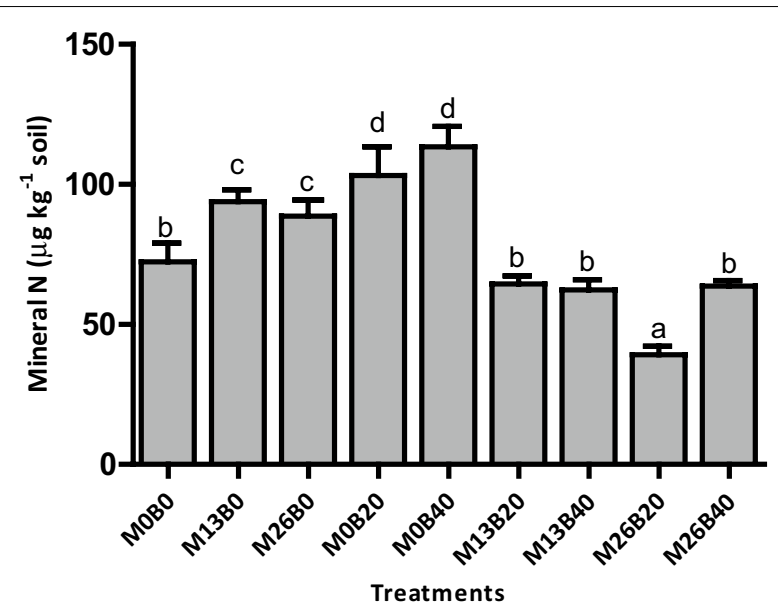

Fig. 5 Effect of treatment on mineral $N$ during the incubation of sandy soils amended with cow manure (M), biochar (B) and B-M mixtures over 56 days. Same letter(s) above the bars indicate no significant difference between treatments at $p=0.05$. Vertical bars represent standard error of the mean $(n=3)$. M0, M13 and M26 are $M$ rates at 0,13 and 26 tons ha ${ }^{-1}$ respectively. BO, B20 and B40 are $B$ rates at 0,20 and 40 tons ha ${ }^{-1}$, respectively

Table 4 Means $(n=3)$ of treatments effect on net $\mathbf{N}$ mineralization in soils treated with manure and biochar

\begin{tabular}{|c|c|c|c|}
\hline \multirow{2}{*}{$\begin{array}{l}\text { Manure (tons } \\
\mathrm{ha}^{-1} \text { ) }\end{array}$} & \multicolumn{3}{|c|}{ Biochar (tons ha ${ }^{-1}$ ) } \\
\hline & $\begin{array}{l}0(\mu \mathrm{g} \mathrm{N} \mathrm{kg-1} \\
\text { soil) }\end{array}$ & $\begin{array}{l}20\left(\mu \mathrm{g} \mathrm{N} \mathrm{kg}{ }^{-1}\right. \\
\text { soil) }\end{array}$ & $\begin{array}{l}40\left(\mu \mathrm{g} \mathrm{N} \mathrm{kg}{ }^{-1}\right. \\
\text { soil) }\end{array}$ \\
\hline 0 & & 30.8 & 41.1 \\
\hline 13 & 21.5 & -7.9 & -10.0 \\
\hline 26 & 16.3 & -33.1 & -8.6 \\
\hline
\end{tabular}

that the onset of priming effect is only few days following addition of organic residues (Blagodatskaya and Kuzyskov 2008) and the incubation conditions employed are ideal, the 56 days incubation period could be equivalent to over a year under field conditions, thus giving an indication of medium to long term priming potential.

Several postulates have been put forward to explain the observed accelerated mineralization of SOC following sole addition of manure or biochar to soils. Rogovska et al. (2011) attributed it to increased activity of aerobes resulting from improved porosity and decreased bulk density of biochar amended soils, leading to increased mineralization of organic compounds. The cattle manure used in our study undoubtedly contained more diverse and quality organic substrates compared to biochar. This condition probably promoted rapid growth and activity of hitherto dormant "r-strategist" and other diverse microbial groups, resulting in induced production and release of more diverse extracellular enzymes (Fontaine et al. 2003; Hamer et al. 2004; Hamer and Marschner 2005a, b), which lead to rapid SOC mineralization and subsequently larger positive priming effect through cometabolisms (Kuzyakov 2010; Zimmerman et al. 2011). Furthermore, because the soil used in our study was sampled from a bare uncultivated land low in fertility, analogous to Liebig's Law of minimum, the manure containing other limiting nutrients, and perhaps younger and more vigorous microbial populations as well as enough organic $\mathrm{C}$, provided conditions needed to meet the minimum "energy threshold" required to colonize and mineralize SOC.

The observed shift from positive (41-124\% increased) to a negative ( -3.50 to $-35 \%$ decreased) priming of native SOC, through the interaction of soil-manure-biochar in the combined manure-biochar treated soils fall in the range reported by other workers (Zavalloni et al. 2011; Zimmerman et al. 2011; Riaz et al. 2017). Laboratory incubation and field studies have shown that application of biochar decreased the mineralization of added $C$ (Kuzyakov et al. 2009; Zimmerman et al. 2011). Application of biochar has been reported to counteract positive priming of SOC by corn plants, resulting in $48 \%$ lower SOC loses (Whitman et al. 2014). The increase in the negative priming effect with increasing biochar application rates observed in this study is consistent with those of Bamminger et al. (2013) who reported biochar induced negative priming effect of -24 and $-38 \%$ at 20 and $40 \%$ application rates, respectively.

Several mechanisms, including protection of organic substrates from microbial use, entrapment of microbial enzymes and/or reduction in soil pore spaces that inhibited gaseous exchange (Zavalloni et al. 2011) have been used to explain the decreased mineralization of SOC following combined application of organic residues and biochar. Negative priming of SOC mineralization has also been attributed to toxicity of combustion products such as dioxins, furans, phenols and poly aromatic hydrocarbons in the biochar to microorganisms (Liu et al. 2009; Spokas et al. 2010). However, if this mechanism were responsible for the observed negative priming effect, it would have manifested in the sole biochar treatments. Given the alkaline nature of the soil and the high $\mathrm{pH}$ of the biochar used in the present study, we hypothesize that the negative priming effect observed in our study was probably due to precipitation or adsorption of mineralizable $\mathrm{C}$ from manure and SOC on the surface of biochar as carbonates (Joseph et al. 2010; Zimmerman et al. 2011), making them unavailable for microbial oxidation. In addition, due to the porous nature and large surface area of biochar, chemisorption of the evolved $\mathrm{CO}_{2}$ on the biochar surface is also likely (Mendez et al. 2013). 
It has been shown that $\mathrm{CO}_{2}$ adsorption capacity of biochar is highly correlated with specific surface areas, with $\mathrm{CO}_{2}$ adsorption increasing with increased pyrolysis temperature (Huang et al. 2015). It is also known that $\mathrm{CO}_{2}$ adsorption capacity of biochar can reach a maximum value due to the limitations imposed by the adsorptive surface of the biochar (Huang et al. 2015; Madzaki et al. 2016; Sigmund et al. 2017). We hypothesize that the observed stronger expression of negative priming effect at higher compared to lower biochar rate at a fixed manure application rates (Fig. 2) was caused by increased labile $\mathrm{C}$ with increasing manure rate, which, upon mineralization released relatively higher level of $\mathrm{CO}_{2}-\mathrm{C}$ that saturated biochar sorption sites. Thus, the increased $\mathrm{CO}_{2}-\mathrm{C}$ released from mineralization of the higher level of labile $\mathrm{C}$ in the higher manure rate saturated the surface and exceeded the upper limit of the amount of $\mathrm{CO}_{2}-\mathrm{C}$ that can be physically adsorbed by the biochar. This, subsequently, resulted in higher net $\mathrm{CO}_{2}$ evolution at the higher manure compared to the lower application rate at a fix biochar rate.

\section{Water extractable organic $\mathrm{C}$ and $\mathrm{Net} \mathrm{N}$ mineralization}

The higher WEOC in soils co-amended with manure and biochar compared to those of the sole amendment suggest a synergistic interaction between components on the surface of biochar and manure to form decomposable compounds that desorbed or transformed into WEOC. Similar results have been reported by Zavalloni et al. (2011) who observed transformation of recalcitrant OM into available $\mathrm{C}$ in soils amended with glucose. The significant correlation between WEOC and the net $\mathrm{CO}_{2}-\mathrm{C}$ efflux from soils treated with manure and biochar indicate that labile $\mathrm{C}$ pool was an important source of $\mathrm{C}$ for the microbes. Other researchers have also attributed the increased microbial activity in soils amended with organic substrates to the high levels of water-soluble organic C (Cross and Sohi 2011).

It is known that net $\mathrm{N}$ mineralization/immobilization depends on the availability of mineral $\mathrm{N}$ in the soil, and organic amendments with $\mathrm{C} / \mathrm{N}$ ratio below 20 results in net $\mathrm{N}$ mineralization, whereas those with wider $\mathrm{C} / \mathrm{N}$ ratios result in inorganic $\mathrm{N}$ immobilization from the soil. Given that the initial mineral N content of the soil is very low (30 $\mathrm{mg} \mathrm{kg} \mathrm{soil}^{-1}$; Table 1$)$, the high $\mathrm{C} / \mathrm{N}$ ratio imposed on the soils due to the combined application of biochar and manure resulted in microbial assimilation of soil mineral $\mathrm{N}$ for cell biosynthesis, leading to the observed negative NNM or N immobilization. The increased $\mathrm{C} / \mathrm{N}$ ratio when manure and biochar were co-applied, limited mineral $\mathrm{N}$ availability, resulting in reduced $\mathrm{C}$ mineralization and negative priming effect. This is consistent with previous studies that reported net
$\mathrm{N}$ immobilization and attributed it to the high $\mathrm{C} / \mathrm{N}$ ratio of the crop residues applied (Novak et al. 2010; Zavalloni et al. 2011; Riaz et al. 2017).

\section{Conclusions}

This study demonstrated that sole application of manure and biochar resulted in significant net $\mathrm{CO}_{2}-\mathrm{C}$ efflux from the soils leading to positive priming of $\mathrm{SOC}$ and higher proportions of the initial $\mathrm{C}$ lost through respiration. Coapplication of biochar and manure decelerate the decomposition of native SOC, probably through adsorption of labile $\mathrm{C}$ and net $\mathrm{N}$ immobilization, resulting in significant decrease in net $\mathrm{CO}_{2}$-C efflux, and subsequently lead to a negative priming effect of $35 \%$. The potential of biochar to counteract positive priming of native SOC with negligible or no impact on mineral $\mathrm{N}$ availability in the short and long-terms in these soils require further investigation.

\section{Authors' contributions}

DED managed the overall conduct of the experiments, conducted literature review, data analysis and drafted the manuscript. YJA contributed to laboratory experiments, data analysis and draft manuscript preparation. FTA contributed to laboratory experiments and data analysis. TAD contributed to data analysis and reviewed the draft manuscript. DN assisted with data analysis and reviewed the draft manuscript. MM assisted with data analysis and reviewed the draft manuscript. All authors read and approved the final manuscript.

\section{Author details \\ ${ }^{1}$ Department of Soil Science, University of Ghana, Legon-Accra, Ghana. ${ }^{2}$ Department of Environmental Sciences, University of Cape Coast, Cape Coast, Ghana.}

\section{Acknowledgements}

The authors are indebted to laboratory technicians at the Department of Soil Science, University of Ghana, Legon for their assistance in the laboratory analysis. Yahaya J. Amanor and Festus T. Attor are grateful to the Department of Soil Science, University of Ghana, Legon for providing the facility and equipment to conduct this research as part of their BSc Dissertation.

\section{Competing interests}

The authors declare that they have no competing of interests.

\section{Availability of data and materials}

Data was generated by author's own field sampling and laboratory analysis.

\section{Consent for publication}

All authors read the manuscript and agreed on its publication.

\section{Ethics approval and consent to participate}

Authors declare that, this manuscript is not published or consider for publication elsewhere.

\section{Funding}

This research did not receive any fund from public, commercial, or not-forprofit agencies.

\section{Publisher's Note}

Springer Nature remains neutral with regard to jurisdictional claims in published maps and institutional affiliations.

Received: 22 January 2018 Accepted: 19 March 2018

Published online: 02 April 2018 


\section{References}

Ameloot N, Graber ER, Verheijen FGA, de Neve S (2013) Interactions between biochar stability and soil organisms: review and research needs. Eur J Soil Sci 64:379-390

Bamminger C, Marschner B, Jüschke E (2013) An incubation study on the stability and biological effects of pyrogenic and hydrothermal biochar in two soils. Eur J Soil Sci 65:72-82

Blagodatskaya E, Kuzyakov Y (2008) Mechanisms of real and apparent priming effects and their dependence on soil microbial biomass and community structure: critical review. Biol Fertil Soils 45:115-131

Cross A, Sohi SP (2011) The priming potential of biochar products in relation to labile carbon contents and soil organic matter status. Soil Biol Biochem 43:2127-2134

Flavel TC, Murphy DV (2009) Carbon and nitrogen mineralization rates after application of organic amendments to soils. J Environ Qual 35:183-193

Fontaine S, Mariotti A, Abbadie L (2003) The priming effect of organic matter: a question of microbial competition? Soil Biol Biochem 35:837-843

Gee GW, Bauder JW (1986) Particle-size analysis. In: Klute A (ed) Methods of soi analysis, part 1, physical and mineralogical methods, 2nd edn. SSSA/ASA, Madison, pp 383-411

Grunwald D, Kaiser M, Ludwig B (2016) Effect of biochar and organic fertilizers on $\mathrm{C}$ mineralization and macro-aggregate dynamics under different incubation temperatures. Soil Tillage Res 164:11-17

Hamer U, Marschner B (2005a) Priming effects in different soil types induced by fructose, alanine, oxalic acid and catechol additions. Soil Biol Biochem 37:445-454

Hamer U, Marschner B (2005b) Priming effects in soils after combined and repeated substrate addition. Geoderma 128:28-51

Hamer U, Marschner B, Brodowski S, Amelung W (2004) Interactive priming of black carbon and glucose mineralization. Org Geochem 35:823-830

Huang Y, Chiueh P, Shih C, Lo S, Sun L, Zhong Y, Qiu C (2015) Microwave pyrolysis of rice straw to produce biochar as an adsorbent for $\mathrm{CO}_{2}$ capture. Energy 84:75-83

Jones DL, Murphy DV, Khalid M, Ahmad W, Edwards-Jones G, DeLuca TH (2011) Short-term biochar-induced increase in soil $\mathrm{CO}_{2}$ release is both biotically and abiotically mediated. Soil Biol Biochem 43:1723-1731

Joseph SD, Camps-Arbestain M, Lin Y, Munroe P, Chia CH, Hook J, van Zwieten L, Kimber S, Cattleie A, Singh BP, Lehmann J, Foid N, Smernik RJ, Amonette JE (2010) An investigation into the reactions of biochar in soil. Soil Res 48:501-515

Kuzyakov Y (2010) Priming effects: interactions between living and dead organic matter. Soil Biol Biochem 42:1363-1371

Kuzyakov Y, Friedel JK, Stahr K (2000) Review of mechanisms and quantification of priming effects. Soil Biol Biochem 32:1485-1498

Kuzyakov Y, Subbotina I, Chen H, Bogomolova I, Xu X (2009) Black carbon decomposition and incorporation into soil microbial biomass estimated by 14C labeling. Soil Biol Biochem 41:210-219

Liang BQ, Lehmann J, Sohi SP, Thies JE, O'Neill B, Trujillo L, Gaunt J, Solomon D, Grossman J, Neves EG, Luizao FJ (2010) Black carbon affects the cycling of non-black carbon in soil. Org Geochem 41:206-213

Liu QS, Liu Y, Show KY, Tay JH (2009) Toxicity effect of phenol on aerobic granules. Environ Technol 30:69-74

Lu W, Ding W, Zhang J, Li Y, Luo J, Bolan N, Xie Z (2014) Biochar suppressed the decomposition of organic carbon in a cultivated sandy loam soil: a negative priming effect. Soil Biol Biochem 76:12-21

Luo Y, Durenkamp M, De Nobili M, Lin Q, Brookes PC (2011) Short term soil priming effects and the mineralisation of biochar following its incorporation to soils of different $\mathrm{pH}$. Soil Biol Biochem 43:2304-2314

Madzaki H, KarimGhani WA, Rebitanim N, Alias AB (2016) Carbon dioxide adsorption on sawdust biochar. Proc Eng 148:718-725
Mendez A, Tarquis AM, Saa-Requejo A, Guerrero F, Gasco G (2013) Influence of pyrolysis temperature on composted sewage sludge biochar priming effect in a loamy soil. Chemosphere 93:668-676

Mulvaney RL (1996) Nitrogen-inorganic forms. In: Sparks DL et al (eds) Methods of soil analysis, part 3, chemical methods, 3rd edn. Madison, SSSA ASA, pp 1123-1184

Novak JM, Busscher WJ, Watts DW, Laird DA, Ahmedna MA, Niandou MAS (2010) Short-term $\mathrm{CO}_{2}$ mineralization after additions of biochar and switchgrass to a typic Kandiudult. Geoderma 154:281-288

Qayyum MF, Steffens D, Reisenauer HP, Schbert S (2012) Kinetics of carbon mineralization of biochars compared with wheat straw in three soils. J Environ Qual 41:1210-1220

Riaz M, Roohi M, Arif SM, Hussain Q, Yasmeen T, Shahzad T, Shahzad SM, Muhammad HF, Muhammad A, Khalid M (2017) Corncob-derived biochar decelerates mineralization of native and added organic matter (AOM) in organic matter depleted alkaline soil. Geoderma 294:19-28

Rittl TF, Novotny EH, Balieiro FC, Hoffland E, Alves BJR, Kuyper TW (2015) Negative priming of native soil organic carbon mineralization by oilseed biochars of contrasting quality. Eur J Soil Sci 66:714-721

Rogovska N, Laird D, Cruse R, Fleming P, Parkin T, Meek D (2011) Impact of biochar on manure carbon stabilization and greenhouse gas emissions. Soil Sci Soc Am J 75:871-879

Sigmund G, Huffer T, Hofmann T, Kah M (2017) Biochar total surface area and total pore volume determined by $\mathrm{N}_{2}$ and $\mathrm{CO}_{2}$ physisorption are strongly influenced by degassing temperature. Sci Total Environ 580:770-775

Sigua GC, Novak JM, Watts DW, Cantrll KB, Shumaker PD, Szogi AA, Johnson MG (2014) Carbon mineralization in two utisols amended with different sources and particle sizes of pyrolyzed biochar. Chemosphere 103:313-321

Smith JL, Collins HP, Bailey VL (2010) The effect of young biochar on soil respiration. Soil Biol Biochem 42:2345-2347

Sohi SP, Krull E, Lopez-Capel E, Bol R (2010) A review of biochar and its use and function in soil. Adv Agron 105:47-82

Spokas KA, Baker JM, Reicosky DC (2010) Ethylene: potential key for biochar amendment impacts. Plant Soil 333:443-452

Troy SM, Lawlor PG, O'Flynn CJ, Healy MG (2013) Impact of biochar addition to soil on greenhouse gas emissions following pig manure application. Soil Biol Biochem 60:173-181

Walkley A, Black CA (1934) An examination of the digestion method for determining soil organic matter and proposed modification of chromic acid titration method. Soil Sci 37:29-38

Wardle DA, Nilsson MC, Zackrisson O (2008) Fire-derived charcoal causes loss of forest humus. Science 320:629

Watanabe S, Sato S (2015) Priming effect of bamboo (Phyllostanchys edulis Carriere) biochar application in a soil amended with legume. Soil Sci Plant Nutr 61:934-939

Whitman T, Enders A, Hanley K, Lehmann J (2013) Predicting pyrogenic organic matter mineralization from its initial properties and implications for carbon management. Org Geochem 64:76-83

Whitman T, Enders A, Lehmann J (2014) Pyrogenic carbon addition to soil counteract positive priming of soil carbon mineralization by plants. Soil Biol Biochem 73:33-41

Zavalloni C, Alberti G, Biasiol S, Vedove GD, Fornasier F, Liu J, Peressotti A (2011) Microbial mineralization of biochar and wheat straw mixture in soil: a short-term study. Appl Soil Ecol 50:45-51

Zimmerman AR (2010) Abiotic and microbial oxidation of laboratory-produced black carbon (biochar). Environ Sci Technol 44:1295-1301

Zimmerman AR, Gao B, Ahn MY (2011) Positive and negative carbon mineralization priming effects among a variety of biochar-amended soils. Soil Biol Biochem 43:169-1179 